\title{
Evaluation of the Use of Activated Carbon Powder for Removal of Emerging Micropollutants from Sewage Wastewater
}

\author{
Juliano César Rego Ferreira ${ }^{1}$, Daniela Neuffer ${ }^{2}$, Karen Juliana do Amaral ${ }^{2,3, *}$ \\ ${ }^{1}$ Companhia de Saneamento do Paraná, Rua Engenheiros Rebouças, Brazil \\ ${ }^{2}$ Industrial Water and Wastewater Technology, University of Stuttgart, Germany \\ ${ }^{3}$ Department of Civil Engineering, Positive University, Brazil
}

Copyright $(2017$ by authors, all rights reserved. Authors agree that this article remains permanently open access under the terms of the Creative Commons Attribution License 4.0 International License

\begin{abstract}
In order to remove micropollutants from wastewater, it is necessary to adopt advanced treatment technologies, one of which is adsorption with activated carbon powder (ACP). This study evaluated the process of ACP adsorption to remove 18 emerging micropollutants from secondary wastewater effluent in the wastewater treatment plant in Büsnau, Stuttgart, Germany. Norit ACP was selected for this study. The contact time was 30 minutes. In this configuration, removal efficiency of pharmaceuticals was higher than $77 \%$ with $10 \mathrm{mg} / \mathrm{L}$ of $\mathrm{ACP}$, and with 30 $\mathrm{mg} / \mathrm{L}$ it was higher than $90 \%$. For PCPs, removal efficiency with $10 \mathrm{mg} / \mathrm{L}$ of ACP varied from $50 \%$ for triethyl citrate and up to $88 \%$ for tonalide (AHTN), while $20 \mathrm{mg} / \mathrm{L}$ removed more than $83 \%$ of each PCP analyzed. For the FROPs, removal rates with $10 \mathrm{mg} / \mathrm{L}$ of $\mathrm{ACP}$ varied from $49 \%$ for N,N-Diethyl-meta-toluamide (TCEP) and $91 \%$ for tris-(1,3-dichloroisopropyl)-phosphate (TDCP), and 20mg/L attained removal rates of $86 \%$ for TCEP and $99 \%$ for TDCP. Finally, MTBT and BT obtained removal levels equal to or higher than $60 \%$ with initial doses of $5 \mathrm{mg} / \mathrm{L}$ of ACP. It was confirmed that treatment with ACP is an efficient solution for the removal of examined emerging micropollutants.
\end{abstract}

Keywords Emerging Micropollutants, Wastewater, Adsorption, Activated Carbon ${ }^{1}$

$1 \mathrm{ACP}$ - activated carbon powder; PCPs - Personal care products; FROPs flame retardants and organophosphate plasticizers; MTBT -

2-mercaptobenzothiazole; BT - benzothiazole; AHTN - tonalide; HHCB galaxolide; AOPs - advanced oxidation practices; GAC - granular activated carbon; BHA - Butylated Hydroxyanisole; BHT - Butylated hydroxytoluene; DEET - N,N-Diethyl-meta-toluamide; TCEP tris(2-carboxyethyl)phosphine; TDCP -

tris-(1,3-dichloroisopropyl)-phosphate; TDCPP - Tris(1,3-dichloro-2-propyl) phosphate TiBP; TCPP - tris(1-chloro-2-propyl) phosphate.

\section{Introduction}

Emerging organic micropollutants are substances that are continually being introduced into the environment. Although they may have a harmful effect on human beings and the environment, micropollutants are still not included in national or international monitoring programs. Some sources of these substances are: pharmaceuticals, personal care products (PCPs), flame retardant and organophosphate plasticizers, among others $[1,2]$.

The primary route of these micropollutants into the environment is through domestic wastewater discharged as end wastewater from water treatment plants (WTPs), or even through discharge of raw wastewater. Various authors have reported the occurrence of different emerging micropollutants in the environment, including in rivers, lakes, seas, groundwater and aquatic organisms [3-9,2], as well as reported occurrences of emerging micropollutants in water that is treated and distributed for human consumption $[10,11]$.

Emerging micropollutants have been found in different concentrations in different locations around the world. Pharmaceuticals stand out, with maximum concentrations of diclofenac of up to $28.4 \mu \mathrm{g} / \mathrm{L}$ in Canada, and up to $22 \mu \mathrm{g} / \mathrm{L}$ of carbamazepine in Germany, where synthetic fragrances such as galaxolide (HHCB) has a maximum value of up to 13.3 $\mu \mathrm{g} / \mathrm{L}$, and up to $6.8 \mu \mathrm{g} / \mathrm{L}$ of tonalide (AHTN). In the United States (USA), DEET insect repellants are reported to be $2.1 \mu \mathrm{g} / \mathrm{L}$. TCPP flame retardant had maximum concentrations of $22 \mu \mathrm{g} / \mathrm{L}$ in Sweden, and in South Korea, TCEP had a maximum concentration of $2.6 \mu \mathrm{g} / \mathrm{L}$. BT and MTBT had maximum concentrations of $22 \mu \mathrm{g} / \mathrm{L}$ in Sweden, and $6.2 \mu \mathrm{g} / \mathrm{L}$ in Spain.

Many of these emerging micropollutants are not removed, or are only partially removed, through conventional wastewater treatment processes. It was confirmed that in low concentrations of $\mathrm{ng} / \mathrm{L}$, endocrine disruptor compounds (for 
example hormones) already cause feminization or masculinization of aquatic organisms [12, 8, 13, 14]. Cleuvers [15] demonstrated that toxicity can be enhanced in mixtures, as the toxicity of carbamazepine and clofibrate acid in Daphnia increased when both pharmaceuticals were mixed in the test. Toxicity is not the only worrying factor; there is also the possibility of conception from other emerging pollutants with special biological effects that are dangerous to the environment.

Different advanced wastewater treatment techniques are being studied for the satisfactory removal of these emerging contaminants, including ozonation, advanced oxidation processes (AOPs), filtration techniques with membranes and adsorption with activated carbon [1, 16, 17]. Among these techniques, those that use activated charcoal powder (ACP) are increasingly used due to their positive results $[18,19]$. There are many studies in the literature about the removal of emerging micropollutants through the activated carbon process, either through the use of ACP or granular activated carbon (GAC), but there are few studies on the use of these technologies in matrices for wastewater treatment from Wastewater Treatment Plants (WWTPs). Activated carbon is mostly used in surface water matrices, waters treated for public supply and even pure waters with only solutes of interest [7, 20-25].

The removal efficiency of the emerging micropollutants through ACP treatment is directly related to the following factors: concentration of organic material present in the wastewater, type and amount of activated carbon, contact time, molecular structure and properties of the contaminants and the configuration adopted for adsorption treatment [17-20]. Other benefits from the use of ACP in wastewater treatment include further reduction of the organic load, removal of phosphorous [18, 19] and reduction of total estrogenic activity from wastewater at levels higher than $99 \%$ [26].

\section{Objectives}

This study aimed to evaluate the removal efficiency of 18 different types of emerging micropollutants found in the secondary wastewater effluent from the Büsnau WWTP, located in Stuttgart, Germany, through treatment with ACP. The substances studied included the pharmaceuticals carbamazepine, diclofenac, lidocaine and mirtazapine, the personal care products (PCPs) HHCB, HHCB-lactone, AHTN, triethyl citrate, BHA, BHT, benzophenone and DEET, and the flame retardants and organophosphate plasticizers (FROPs) TCEP, TCPP, TDCP and TiBP, and other MTBT and BT compounds.

\section{Methods}

This experimental study was developed in a laboratory. The study consisted of determination and analysis of the occurrence of emerging micropollutants in the secondary wastewater effluent from samples collected in the Büsnau WWTP; selection of emerging micropollutants and types of activated carbon to be evaluated; and experiments for the removal of the selected contaminants from the secondary wastewater effluent from the WWTP with ACP.

\subsection{Büsnau Wastewater Treatment Plant (Büsnau WWTP)}

The Büsnau WWTP is a tertiary treatment system to remove nitrogen and phosphorous, with a treatment capacity of $30 \mathrm{~L} / \mathrm{s}$. This WWTP receives a load equivalent to 10,000 residents, with removal efficiency of COD from the WWTP higher than $95 \%$. The system is operated by the University of Stuttgart, and performs treatment of part of the wastewater generated in the suburbs of Stuttgart, including Lauchhau in the north zone of Vaihingen, and the University of Stuttgart region, also in the Pfaffenwald region of Vaihingen. The WWTP is also used as the experimental plant for different research and studies in the field of wastewater treatment by the Institute for Sanitation Engineering, Water Quality and Solid Waste Management (ISWA) of the University of Stuttgart.

\subsection{Selection of ACP Type and Emerging Micropollutants}

This study used NORIT ${ }^{\circledR}$ SAE SUPER activated carbon by Cabot, because previous evaluation (not addressed in this article) showed that this brand had the best results for micropollutant removal.

Table 1 lists the primary characteristics of the selected activated carbon.

Table 2 shows the micropollutants analyzed in this study and some of their properties. The compounds are divided into pharmaceuticals, personal care products, flame retardant and organophosphate plasticizers, and others (MTBT and BT). 
Table 1. Characteristics of activated carbon powder used and its primary properties

\begin{tabular}{|c|c|}
\hline Characteristics/ properties & NORIT SAE SUPER \\
\hline Brand name & Norit \\
\hline Common name & 1050 \\
\hline Iodine number $(\mathrm{mg} / \mathrm{g})$ & 28 \\
\hline Adsorption in methylene blue $(\mathrm{g} / 100 \mathrm{~g})$ & 1150 \\
\hline BET Surface Area $\left(\mathrm{m}^{2} / \mathrm{g}\right)$ & 15 \\
\hline Mean particle diameter $(\mu \mathrm{m})$ & \\
\hline
\end{tabular}

Table 2. Emerging micropollutants evaluated and their primary physicochemical properties

\begin{tabular}{|c|c|c|c|c|c|}
\hline Substances & CAS No & $\begin{array}{l}\text { Molecular } \\
\text { Formula }\end{array}$ & $\begin{array}{l}\text { Molar Mass } \\
(\mathrm{g} / \mathrm{mol})\end{array}$ & $\log \mathrm{K}_{\mathrm{OW}}$ & $\begin{array}{l}\text { Water solubility at } \\
25^{\circ} \mathrm{C}(\mathrm{mg} / \mathrm{L})\end{array}$ \\
\hline \multicolumn{6}{|c|}{ Pharmaceuticals } \\
\hline Carbamazepine & $298-46-4$ & $\mathrm{C}_{15} \mathrm{H}_{12} \mathrm{~N}_{2} \mathrm{O}$ & 236.28 & 2.45 & 112 \\
\hline Diclofenac & $15307-86-5$ & $\mathrm{C}_{14} \mathrm{H}_{11} \mathrm{Cl}_{2} \mathrm{NO}_{2}$ & 296.16 & 4.51 & 2.37 \\
\hline Lidocaine & $137-58-6$ & $\mathrm{C}_{14} \mathrm{H}_{22} \mathrm{~N}_{2} \mathrm{O}$ & 234.4 & 2.44 & 4.100 \\
\hline Mirtazapine & $85650-52-8$ & $\mathrm{C}_{17} \mathrm{H}_{19} \mathrm{~N}_{3}$ & 265.35 & 3.1 & 9.800 \\
\hline \multicolumn{6}{|c|}{ Personal care products } \\
\hline HHCB & $1222-05-5$ & $\mathrm{C}_{18} \mathrm{H}_{26} \mathrm{O}$ & 258.41 & 5.9 & 1.75 \\
\hline HHCB-Lactone & $256393-37-0$ & $\mathrm{C}_{18} \mathrm{H}_{24} \mathrm{O}_{2}$ & 272.38 & 4.71 & 8.2 \\
\hline AHTN & $21145-77-7$ & $\mathrm{C}_{18} \mathrm{H}_{26} \mathrm{O}$ & 258.41 & 5.7 & 1.25 \\
\hline DEET & $134-62-3$ & $\mathrm{C}_{12} \mathrm{H}_{17} \mathrm{NO}$ & 191.28 & 2.18 & 912 \\
\hline BHA & $25013-16-5$ & $\mathrm{C}_{22} \mathrm{H}_{32} \mathrm{O}_{4}$ & 360.5 & 3.5 & 213 \\
\hline BHT & $128-37-0$ & $\mathrm{C}_{15} \mathrm{H}_{24} \mathrm{O}$ & 220.36 & 5.1 & 0.6 \\
\hline Benzophenone & $119-61-9$ & $\mathrm{C}_{13} \mathrm{H}_{10} \mathrm{O}$ & 182.22 & 3.18 & 137 \\
\hline Triethyl citrate & $77-93-0$ & $\mathrm{C}_{12} \mathrm{H}_{20} \mathrm{O}_{7}$ & 276.29 & 0.33 & 65.000 \\
\hline \multicolumn{6}{|c|}{ Flame retardant and organophosphate plasticizers } \\
\hline TCEP & $115-96-8$ & $\mathrm{C}_{6} \mathrm{H}_{12} \mathrm{Cl}_{3} \mathrm{O}_{4} \mathrm{P}$ & 285.49 & 1.44 & 7.000 \\
\hline TCPP & $13674-84-5$ & $\mathrm{C}_{9} \mathrm{H}_{18} \mathrm{Cl}_{3} \mathrm{O}_{4} \mathrm{P}$ & 327.57 & 2.59 & 1.200 \\
\hline TDCPP & $13674-87-8$ & $\mathrm{C}_{9} \mathrm{H}_{18} \mathrm{Cl}_{6} \mathrm{O}_{4} \mathrm{P}$ & 430.91 & 3.65 & 7 \\
\hline TiBP & $126-71-6$ & $\mathrm{C}_{12} \mathrm{H}_{27} \mathrm{O}_{4} \mathrm{P}$ & 266.32 & 3.60 & 16.2 \\
\hline \multicolumn{6}{|c|}{ Other compounds } \\
\hline MTBT & $615-22-5$ & $\mathrm{C}_{8} \mathrm{H}_{7} \mathrm{NS}_{2}$ & 181.28 & 3.15 & 125 \\
\hline $\mathrm{BT}$ & $95-16-9$ & $\mathrm{C}_{7} \mathrm{H}_{5} \mathrm{NS}$ & 135.19 & 2.01 & 4.300 \\
\hline
\end{tabular}

Source: Adapted from Syracuse Research Corporation, (2011) and Dagenais et al., 2009 [27].

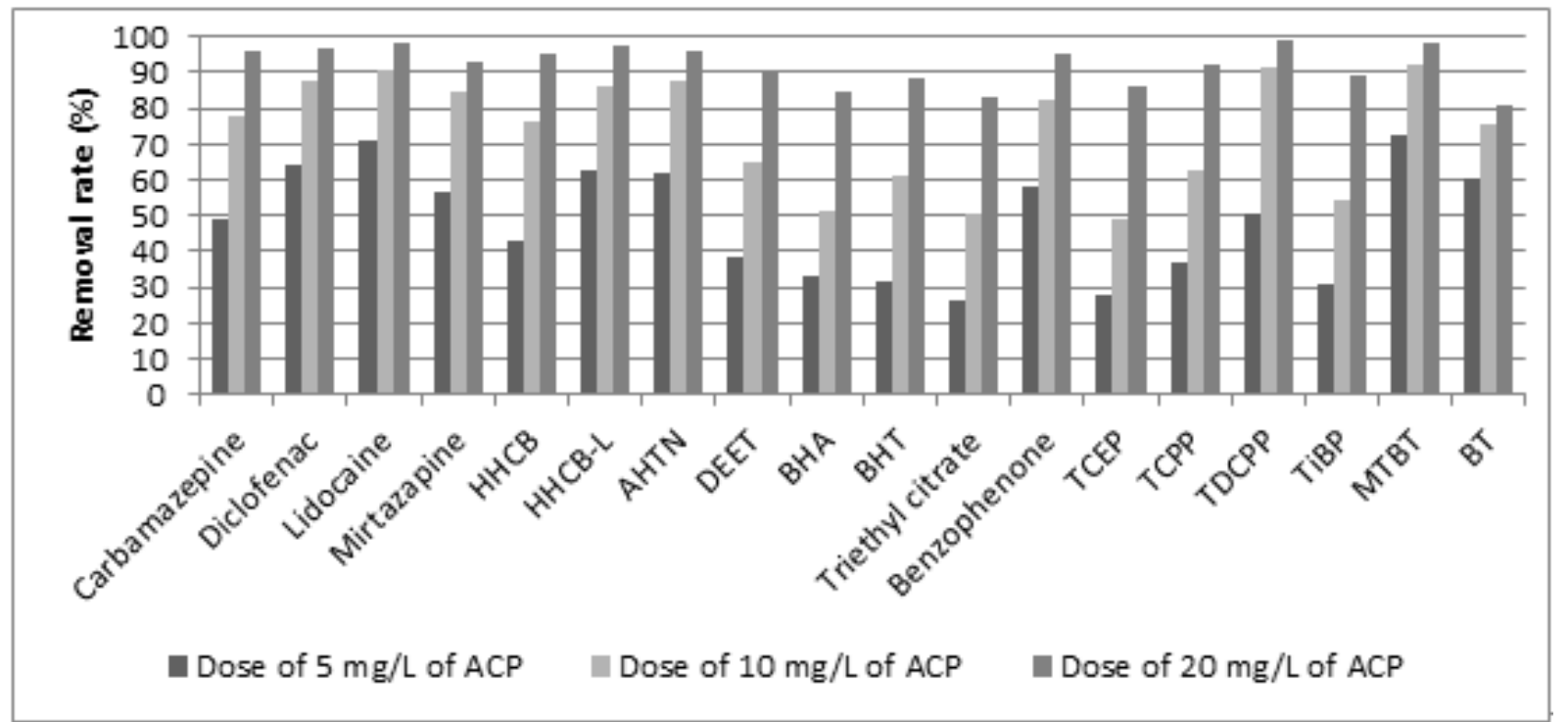

Figure 1. Removal rates of micropollutants through treatment with different amounts of Norit activated carbon powder (ACP), with a contact time of 30 minutes. 


\subsection{ACP Treatment and Quantification of Micropollutants}

The amounts of 5, 10, 20 and $40 \mathrm{mg} / \mathrm{L}$ of the selected ACP were used to evaluate the removal efficiency of the emerging micropollutants. Up to $20 \mathrm{mg} / \mathrm{L}$ of ACP is considered to be economically viable $[25,18,19]$, and $40 \mathrm{mg} / \mathrm{L}$ of ACP was adopted to permit extrapolations from the results of removal of the emerging contaminants.

The contact time adopted was 30 minutes. This amount of time was considered ideal through a previous evaluation (not treated in this article), and that, according to Metzger and Kapp [18] and Zwickenpflug et al. [19], is the time limit for this type of study. The wastewater from the secondary decanter of the Büsnau WWTP was used as the matrix for the treatment. The sample was stored in a dark, acclimatized room at a temperature of $4^{\circ} \mathrm{C}$, to avoid microbiological activity, and thus variation in the concentration of the micropollutants to be analyzed.

The application of the different amount of ACP was done in a one-liter sample of wastewater, through suspension solution in deionized water, to avoid possible losses of carbon. In order to promote the reaction during the contact time, devices for magnetic agitation were used, and separation of the carbon from the wastewater samples was done through the process of filtration under pressure, with an approximate pressure of 3 bar. The filtering material used was cellulose nitrate filters with a pore size of $0.45 \mu \mathrm{m}$. After treatments with $\mathrm{ACP}$, the samples underwent liquid phase extraction with dichloromethane, and quantification by gas chromatography-mass spectrometry (GC/MS).

\section{Results}

Figure 1 shows the results of removal by ACP treatment for the 18 emerging micropollutants evaluated in this study, at 5,10 and $20 \mathrm{mg} / \mathrm{L}$ of Norit Carbon, with a treatment time of 30 minutes.

The results attained for $5 \mathrm{mg} / \mathrm{L}$ of ACP removed more than $25 \%$ of all of the micropollutants evaluated, and about $70 \%$ for lidocaine and MTBT, and $10 \mathrm{mg} / \mathrm{L}$ of ACP had removal rates that varied from $49.3 \%$ to $92 \%$ for the compounds TCEP and MTBT, respectively. For $20 \mathrm{mg} / \mathrm{L}$, the removal rates were higher than $80 \%$ for all of the substances.

\section{Discussion}

In this study, the removal rates for pharmaceuticals with $10 \mathrm{mg} / \mathrm{L}$ of ACP had results higher than $77 \%$, similar to the results found by Metzger and Kapp [18], who had an average removal rate of $80 \%$ for the 67 pharmaceuticals they evaluated. However, the authors reused the ACP in the biological treatment phase, which increases the efficiency of removal of the treatment, as verified by Zwickenpflug et al.
[19], who attained an increase of about $20 \%$ to $40 \%$ in the removal of the pharmaceuticals and other micropollutants with this practice. The removal rate of carbamazepine attained in this study was $77.7 \%$, and $87.4 \%$ for diclofenac; at the same amount and without recycling the ACP, Zwickenpflug et al. [19] found removal rates of $77 \%$ and $68 \%$ for these pharmaceuticals, respectively. Yet at the same amount with reuse of the ACP carried over from the biological treatment, the removal rates attained by the authors were $96 \%$ for carbamazepine and $86 \%$ for diclofenac.

In this study, the removal rates attained for both carbamazepine and diclofenac were about $96 \%$ at $20 \mathrm{mg} / \mathrm{L}$ of ACP. Metzger and Kapp [18] attained similar results for 20 $\mathrm{mg} / \mathrm{L}$ of ACP reusing the carbon carried over from the biological treatment, with removal higher than $95 \%$ for diclofenac and close to $100 \%$ for carbamazepine.

Considerable results were obtained in the removal of PCPs, even at $5 \mathrm{mg} / \mathrm{L}$ of ACP, varying from $27 \%$ for triethyl citrate to $63 \%$ for HHCB-Lactone, and $10 \mathrm{mg} / \mathrm{L}$ of ACP attained removal rates from $50 \%$ to $88 \%$, respectively. Removal rates were higher than $83 \%$ for all of the PCPs, reaching $97 \%$ for HHCB-Lactone, with $20 \mathrm{mg} / \mathrm{L}$. At $5 \mathrm{mg} / \mathrm{L}$, the removal rates for TCEP and MTBT varied from 28 to $73 \%$, respectively, while at $10 \mathrm{mg} / \mathrm{L}$, the removal efficiency for TCEP reached $49 \%$, and $92 \%$ for MTBT. At $20 \mathrm{mg} / \mathrm{L}$, the compound that had the lowest removal rate was BT at $80 \%$, while TCEP had a result of $86 \%$. For this amount, the compounds that attained the best removal results were MTBT and TDCPP, with values higher than $98 \%$.

Some substances which previously had insignificant removal rates through the ozonation process, including chlorinated organophosphate flame retardant TCEP, TCPP and TDCPP [13], as well as partial removals of around $60 \%$, such as HHCB-Lactone, AHTN, DEET and TiBP $[13,28,29]$, attained removal rates higher than $80 \%$ with $20 \mathrm{mg} / \mathrm{L}$ of ACP.

\section{Conclusions}

The results from this study show that adsorption with ACP is an efficient process to remove emerging micropollutants, even with amounts considered to be economically viable, up to $20 \mathrm{mg} / \mathrm{L}$.

In addition to the efficiencies found in this experiment, a possible removal efficiency gain by about 20 to $40 \%$ through the reuse of the ACP in the biological treatment, as reported by different authors. However, this practice is not appropriate in cases where the sludge from the wastewater is recycled for agricultural purposes. The use of the loaded ACP in the biological treatment would make use in agriculture unviable, and it should be properly disposed of separately from the wastewater sludge, which can be reused for agricultural purposes.

It was verified that ACP treatment promotes the removal 
of emerging micropollutants that remain through processes currently used in WWTPs, and may bring other benefits such as the reduction of the COD in the effluent, the elimination of phosphorous, reduction of toxicity and estrogenicity of the wastewater, and could contribute to wastewater sanitization.

The treatment process with ACP was shown to be capable of efficiently removing the majority of emerging micropollutants found in the wastewaters from WWTPs. Additionally, the results for ozone treatment of recalcitrant compounds such as TCEP, TCPP and TDCPP had removal rates higher than $85 \%$.

For continuity of this study, experiments with ACP treatment on a pilot scale is recommended, in order to certify the efficiency of removal of these contaminants, and establish operation criteria that better meet the needs of the Büsnau WWTP such as: the ideal amount of ACP, contact time and length of time of the ACP during treatment, and sizing criteria.

\section{Acknowledgements}

The authors would like to thank the University of Stuttgart, the Federal University of Paraná and the Brazilian National Service for Industrial Apprenticeship in Paraná for supporting this research. Herr Dr. rer. nat. Bertram Kuch, Department of Hydrochemistry and Hydrobiology at the Institute for Sanitary Engineering, Water Quality and Solid Waste Management, University of Stuttgart, Germany, for his laboratory support. The authors also would like to thank Isabella Kenfield for her help with translation and preparation of the article for submission.

\section{REFERENCES}

[1] Ternes, T. A., Stüber, J., Herrmann, N., McDowell, D., Ried, A., Kampmann, M., Teiser, B., 2003. Ozonation: A Tool for Removal of Pharmaceuticals, Contrast Media and Musk Fragrances From Wastewater? Water Res. 37, pp. 1976-1982.

[2] Reemtsma, T., Quintana, J.B.; Rodil, R., Gárcia-López, M., Rodríguez, I., 2008. Organophosphorus Flame Retardants and Plasticizers in Water in Air: I. Occurrence and Fate. Trends Anal. Chem., 27(9), pp. 727-734.

[3] Heberer, T., 2002a. Occurrence, Fate, and Assessment of Polycyclic Musk Residues in the Aquatic Environment of Urban Areas - A Review. Acta Hydrobiol. 30, pp. 227-243.

[4] Heberer, T., 2002b. Tracking Persistent Pharmaceutical Residues from Municipal Sewage to Drinking Water. J. Hydrol. 266, pp. 175-189.

[5] Weigel, S., Kuhlmann, J., Hühnerfuss, H., 2002. Drugs and Personal Care Products as Ubiquitous Pollutants: Occurrence and Distribution of Clofibric Acid, Caffeine and DEET in the North Sea. Sci. Total Environ. 295, pp. 131-141.

[6] Weigel, S., Berger, U., Jensen, E., Kallenborn, R., Thoresen,
H., Hühnerfuss. Drugs and personal care products as ubiquitous pollutants: occurrence and distribution of clorifibric acid, caffeine and DEET in the North Sea. The Science of the Total Environment, v.295, 2002.

[7] Alder, A. C., Bruchet, A., Carballa, M., Clara, M., Joss, A., Löfler, D., Mcardell, C. S., Miksch, K., Omil, F.; Tuhkanen, T.; Terner, T.A., 2006. Consumption and occurrence, in: Ternes, T.A., Joss, A. (Eds.), Human Pharmaceuticals, Hormones and Fragrances: the Challenge of Micropollutants in Urban Water Management. IWA Publishing, London.

[8] Bester, K., 2007a. Synthetic Fragrance Compounds in the Environment, in: Bester, K. (Ed.), Personal Care Compounds in the Environment Pathways, Fate and Methods for Determination. ${ }^{\text {st }}$ Ed. Weinhein: Wiley-Vch Verlag Gmbh \& Co, Kgaa.

[9] Bester, K., 2007b. Diverse Compounds, in: Bester, K. (Ed.), Personal Care Compounds in the Environment Pathways, Fate and Methods for Determination. $1^{\text {st }}$ Ed. Weinhein: Wiley-Vch Verlag Gmbh \& Co, Kgaa.

[10] Stackelberg, P. E., Furlong, E.D., Meyer, M. T., Zaugg, S. D., Henderson, A. K., Reissman, D.B., 2004. Persistence of Pharmaceutical Compounds and Other Organic Wastewater Contaminants in a Conventional Drinking-Water-Treatment Plant. Sci. Total Environ. 329, pp. 99-113.

[11] Stackelberg, P. E., Gibs, J., Furlong, E. D., Meyer, M.T., Zaugg, S. D., Lippincott, R.L., 2007. Efficiency of Conventional Drinking-Water-Treatment Process in Removal of Pharmaceuticals and Other Organic Compounds. Sci. Total Environ., 377, pp. 255-272.

[12] Kloepfer, A., Jekel, M., Reemtsma, T., 2005. Occurrence, Sources and Fate of Benzothiazoles in Municipal Wastewater Treatment Plants. Environ. Sci. Technol. 39, pp.3792-3798.

[13] Andresen, J. S., Weigel, S., Bester, K., 2007. Organophosphates, flame-retardants and plasticizers, in: Bester, K. (Ed.), Personal Care Compounds in the Environment Pathways, Fate and Methods for Determination. $1^{\text {st }}$ Ed. Weinhein: Wiley-Vch Verlag Gmbh \& Co, Kgaa.

[14] Zhang, Y., Geißen, S., Gal, C. 2008. Carbamazepine and Diclofenac: Removal in Wastewater Treatment Plants and Occurrence in Water Bodies. Chemosphere. 78, pp. $1151-1161$.

[15] Cleuvers, M., 2003. Aquatic Ecotoxicity of Pharmaceuticals Including the Assessment of Combination Effects. Toxicol. Lett.142, pp. 185-194.

[16] Joss, A., Carballa, M., Kreuzinger, N., Siegrist, H., Zabczynski, S., 2006. Wastewater treatment, in: Ternes, T.A., Joss, A. (Eds.) Human Pharmaceuticals, Hormones and Fragrances: the Challenge of Micropollutants in Urban Water Management. IWA Publishing, London.

[17] Snyder, S. A., Adham, S., Redding, A. M., Cannon, F.S., Decarolis, J., Oppenheiner, J., Wert, E.C., Yoon, Y., 2007. Role of Membranes and Activated Carbon in the Removal of Endocrine Disruptors and Pharmaceuticals. Desalination. 202, pp. 156-181

[18] Metzger, S., Kapp, H. 2008. Einsatz Von Pulveraktivkohle Zur Elimination Von Mikroverunreinigungen. VSA Fachtagung, 28, October. 
[19] Zwickenpflug, B., Böhler, M., Sterkele, B., Joss, A., Siegrist, H., Traber, J., Gujer, W., Behl, M., Dorusch, F., Hollender, J., Ternes, T., Fink, G., 2010. Einsatz Von Pulveraktivkohle Zur Elimination Von Mikroverunreinigungen Aus Kommunalem Abwasser: Abschlussbericht. Eidgenössische Anstalt Für Wasserversorgung, Abwassereinigung Und Gewässerschutz, Düdendorf.

[20] Westerhoff, P.; Yoon, Y.; Snyder, S.; Wert, E. Fate of Endocrine Disruptor, Pharmaceutical, and Personal Care Products Chemicals during Simulated Drinking Water Treatment Process. Environment Science and Technologie v. 39, 2005.

[21] Kim, S. D., Cho, J., Kim, I. S., Vanderford, B. J., Snyder, S. A. (2007). Occurrence and Removal of Pharmaceuticals and Endocrine Disruptors in South Korean Surface, Drinking, and Waste Waters. Water Res., 41, pp. 1013-1021.

[22] Bundy, M. M., Doucette, W.J., McNeill, L., Ericson, J.F., 2007. Removal of Pharmaceuticals and Related Compounds by Bench-Scale Drinking Water Treatment System. J. Water Supply: Res. Technol.--AQUA. 56.2, pp. 105-115.

[23] Vieno, N. M., Härkki, H., Tuhkanen, T., Kronberg, L., 2007. Occurrence of Pharmaceuticals in River Water and Their Elimination in a Pilot-Scale Drinking Water Treatment Plant. Environ. Sci. Technol 41, pp. 1432-1442.

[24] Verliefde, A. R. D., Heijman, S. G. J., Cornelissen, E. R., Amy, G., Van Der Bruggen, B., Van Dijk, J.C., 2007. Influence of Electrostatic Interactions on the Rejection with $\mathrm{Nf}$ and Assessment of the Removal Efficiency During Nf/Gac Treatment of Pharmaceutical Active Compounds in Surface Water. Water Res. 41, pp. 3227-3240.
[25] Nowotny, N., Epp, B., Von Sonntag, C., Fahlenkamp, H., 2007. Quantification and Modeling of the Elimination Behavior of Ecologically Problematic Wastewater Micropollutants by Adsorption on Powdered and Granulated Activated Carbon. Environ. Sci. Technol.. 41, pp. 2050-2055.

[26] Lange, C., Kuch, B., Metzger, J. W., 2013. Determination of the Occurrence and Elimination of Endocrine Disrupting Compounds (EDCS) in Municipal Wastewater Treatment Plants (WWTP). Book of Abstracts, Istanbul International Solid, Waste, Water and Wastewater Congress, Turkey, Istanbul, 22-24.05.2013.

[27] Dagenais, C., Avdeef, A., Tsinman, O., Dudley, A., Beliveau, R., 2009. P-Glycoprotein Deficient Mouse In Situ Blood-Brain Barrier Permeability and its Prediction Using an In Combo Pampa Model. Eur. J. Pharm. Sci., 38, pp. 121-137.

[28] Hollender, J., Zimmermann, S.G., Koepke, S., Krauss, M., Mcardell, C.S., Ort, C., Singer, H., Gunten, U.V., Siegrist, H., 2009. Elimination of Organic Micropollutants in a Municipal Wastewater Treatment Plant Upgraded With a Full-Scale Post-Ozonation Followed by Sand Filtration. Environ. Sci. Technol. 43, pp. 7862-7869.

[29] Schaar, H., Clara, M., Gans, O., Kreuzinger, N., 2010. Micropollutant Removal During Biological Wastewater Treatment and Subsequent Ozonation Step. Environ. Pollute. (Oxford, U. K.), 158, pp. 1399-1404.

[30] Syracuse Research Corporation. Interactive Physprop Database Demo. Available at:

Http://www.Syrres.Com/What-We-Do/Databaseforms.Aspx ?Id=386 Accessed on: 10/04/2011. 